Sains Malaysiana 49(2)(2020): 349-356

http://dx.doi.org/10.17576/jsm-2020-4902-13

\title{
Orthodontic Considerations in Bone Graft Selection for Alveolar Cleft Repair
}

(Pertimbangan Ortodontik dalam Pemilihan Graf Tulang untuk Pembaikan Klef Alveolus)

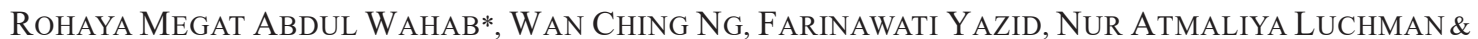 \\ SHAHRUL HISHAM ZAINAL ARIFFIN
}

\begin{abstract}
The enthusiastic development of non-autogenous bone graft materials to correct oral cleft defects in dentistry is founded on arguments of post-operative morbidity and quantity limitation when using conventional iliac crest bone grafts. While success in tooth movement is usually reported for the grafted extraction socket, the results cannot be extrapolated to congenital alveolar clefts as there are differences in terms of vasculature and soft tissue support. This paper provides an overview of the dental and skeletal anomalies in cleft patients, followed by the orthodontic implications of cleft correction and, lastly, a review of the available evidence in bone grafts used for alveolar clefts alone. The nonautogenous grafts used are derived from another human (allografts), animal (xenografts), synthetic bones (alloplasts) or the latest tissue-engineered graft material. The main advantage of using these grafts is a reduction in the number of operative sites. The drawbacks are cost, reduced tooth movement, possibility of root resorption and host reaction. Tissue-engineered grafts seem promising but there is still a lack of clinical trials in human subjects. Important properties related to orthodontics are the graft resorption rate, along with the effect on root resorption and tooth movement rate. To date, autogenous bone grafts remain the first choice for cleft repair.
\end{abstract}

Keywords: Alveolar bone graft; autogenous bone; cleft palate; orthodontic tooth movement; tissue engineering

\section{ABSTRAK}

Kadar morbiditi yang tinggi setelah pembedahan graf tulang alveolar serta keterbatasan kuantiti tulang penderma daripada kresta iliak mencetuskan perkembangan pesat dalam teknologi penghasilan graf tulang bukan autogenus. Graf tulang bukan autogenus telah dilaporkan mampu menyokong pergerakan gigi secara ortodontik merentasi soket cabutan. Namun begitu, pergerakan gigi mungkin terhalang sekiranya graf tersebut digunakan pada defek yang lebih besar seperti klef alveolus kongenital. Ini disebabkan perbezaan daripada segi vaskularisasi dan sokongan tisu lembut antara kedua-dua jenis defek tersebut. Artikel ini membincangkan tentang anomali pergigian dan rahang pesakit klef bibir dan/atau lelangit, implikasi ortodontik terhadap pembetulan klef dan rumusan perkembangan semasa graf tulang yang digunakan dalam defek tulang alveolar. Sumber graf tulang bukan autogenus boleh diperoleh daripada manusia lain (alograf), haiwan (xenograf), bahan sintetik (aloplas) atau disediakan secara kejuruteraan tisu. Kelebihan utama penggunaan graf bukan autogenus adalah pengurangan bilangan kawasan pembedahan manakala kelemahannya termasuk kos yang tinggi, pergerakan gigi yang terhad dan kemungkinan berlakunya penyerapan akar gigi serta tindak balas tubuh badan perumah yang negatif. Penggunaan graf daripada teknologi kejuruteraan tisu mempunyai potensi yang memberangsangkan tetapi masih memerlukan lebih banyak bukti daripada kajian klinikal. Ciri-ciri penting sesuatu graf yang perlu dipertimbangkan dalam bidang ortodontik adalah kadar penyerapan graf, selain kesan terhadap penyerapan akar dan kadar pergerakan gigi. Sehingga kini, graf tulang autogenus masih menjadi pilihan dan merupakan kaedah piawai dalam rawatan pembetulan klef tulang alveolar.

Kata kunci: Graftulang alveolar; kleflelangit; kejuruteraan tisu; pergerakan gigi secara ortodontik; tulang autogenus

\section{INTRODUCTION}

The presence of healthy and sufficient bone is important in orthodontics as applied forces cause continuous deposition and resorption of alveolar bone, resulting in tooth movement (Meikle 2005; Zainal Ariffin et al. 2011). This becomes a problem in cleft alveolus and palate patients. Surgical repair via alveolar bone grafting is carried out to bridge the defect and to prevent progressive loss of periodontal support at the teeth adjacent to the cleft site (Boyne \& Sands 1976). The orthodontist in the cleft team will prepare adequate space for surgical access and correct the malocclusion after surgery. It is therefore important that graft selection does not hamper any orthodontic movements later.

The current gold standard is the use of an autogenous iliac bone graft as it is biocompatible and fulfils all the graft properties to regenerate new bone (Janssen et al. 2014; Reichert et al. 2010). Nevertheless, the constant debate on post-operative morbidity risks has led researchers to look into other substitutes to completely replace or expand autogenous bone (Guo et al. 2011; Weissler et al. 2016). Reichert et al. (2010) reviewed the effects of different 
non-autogenous grafts on tooth movement across all types of alveolar defects. However, orthodontic tooth movement is characterized by sequential events in bone remodelling (i.e. activation, bone resorption, reversal and then bone formation) (Abdul Wahab et al. 2014) that are highly dependent on blood supply. Hence, the tooth movement behaviour across an extraction socket defect - especially in the mandible - or a cystic defect cannot be extrapolated to an alveolar cleft due to differences in bone type, defect size and amount of vasculature (Cohen \& Cohen-Lévy 2014; Politis et al. 2016). As tissue engineering is a fastchanging area of research, we aim to reassess the impact of non-autogenous bone grafting for orthodontic tooth movement in cleft cases specifically.

\section{EFFECTS OF CLEFT LIP AND/OR PALATE ON TOOTH AND ARCH DEVELOPMENT}

The prevalence of cleft lip and/or palate (CLP) within the Asian population (1.19/1000 births) does not differ much between the Chinese, Japanese and other Asian countries but is significantly different than the Caucasian population (1.00/1000 births) (Cooper et al. 2006). In Malaysia, the incidence was 1.24 per 1000 livebirths, with the Chinese affected most frequently and Malay affected the least (Boo \& Arshad 1990). There is a higher proportion of unilateral CLP with predilection to the left side (Cheng et al. 2013; Shah et al. 2015).

Dental development in cleft patients is affected either as a direct attribute of the cleft or as a consequence of early repair. In the cleft locality, the lateral incisor is the most commonly affected tooth in terms of presence, size, shape and root development (López-Giménez et al. 2018; Weissler et al. 2016). Supernumerary teeth are found in $20 \%$ of cases (Weissler et al. 2016), usually distal to the cleft side (De Menezes et al. 2012). Hypodontia of the lateral incisor occurs in more than half of cases; hypodontia of teeth beyond the cleft site occurs in almost a third (Dewinter et al. 2003). Fortunately, the severity of hypodontia is not related to the extent of the cleft (LópezGiménez et al. 2018). Root development of the permanent cleft-side lateral incisor is delayed (Celebi et al. 2015) and overall tooth size is reduced three-dimensionally (Zhou et al. 2013).

A 2-year longitudinal study of 602 infants in Denmark found bimaxillary retrognathia and reduced posterior height of the maxilla when cleft palate is present (Kreiborg et al. 2013). Crossbite was present more frequently in the primary dentition when the cleft width was narrow at infancy in patients with unilateral CLP (Reiser et al. 2010). Cleft width, however, was not correlated to the presence of crossbite in cleft palate patients. This was postulated to be due to the effects of nasoalveolar moulding and early lip repair on the anterior premaxilla segment (Reiser et al. 2010). The resulting maxillary hypoplasia usually necessitates correction via Le Fort I maxillary advancement around the age of 18 years old; in cleft patients the surgical relapse risk is increased (da Silva et al. 2018).
Extraorally, the cleft patient will exhibit a significantly wider alar base root width, a flattened nose and a broader nostril floor width on the cleft side. The upper lip tended to be shorter in length but wider, with thinner upper vermillion thickness (Siti Adibah \& Noor Airin 2016; Zreaqat et al. 2012). Despite the appearance, the nasal airway function is not affected when assessed in adulthood (Reiser et al. 2011).

\section{ALVEOLAR BONE GRAFTING AND ORTHODONTIC CONSIDERATIONS}

The oral health-related quality of life (OHRQoL) in non-syndromic CLP patients is significantly lower than in the normal population, especially for the domains of functional well-being and social-emotional well-being (Antonarakis et al. 2013). However, the OHRQoL improved with surgical treatment of the cleft and was positively correlated with patients and their parents' treatment satisfaction (Munz et al. 2011). Surgical repair of the cleft palate with a bone graft is considered the standard of care. Alveolar bone grafting $(\mathrm{ABG})$ is used to close off the oronasal communication, improve oral hygiene by avoiding nasal leakage, stabilize the maxillary arch and provide a continuous alveolar ridge for eruption of canines, enhance support of the alar base and avoid prosthetic reconstruction (Dewinter et al. 2003).

Surgery before the eruption of canines (termed early secondary $\mathrm{ABG}$ or ' $\mathrm{SABG}$ ') is preferred because it does not stunt growth at the middle face and premaxilla region, it facilitates tooth eruption, which in return provides functional loading to the graft, and it has a higher graft uptake rate (Lilja 2009; Weissler et al. 2016). The age for surgery is still a point of contention: one author posited that surgery done before eruption of central incisors will prevent their eruption into the cleft (Miller et al. 2010), instead assisting in early maxillary arch restoration, providing bone for incisor eruption and lessening the future surgical and orthodontic burden. However, the study lacks long-term follow-up on the anteroposterior and transverse maxilla growth. Grafting when the permanent canine root is a quarter to two-thirds formed is still the popular choice (Lilja 2009).

Infant orthopaedics (IO), including nasoalveolar moulding, is advocated in certain centres to improve facial appearance, ease lip surgery and stimulate maxillary growth. This view is debatable as there was no difference in facial appearance after the age of 6 years between children who had and had not undergone IO when viewed by laymen (Bongaarts et al. 2008). A systematic review found insufficient evidence to support the orthodontic benefits of IO in the long term (Uzel \& Alparslan 2011). Pre-surgical orthodontic treatment is carried out before ABG to align teeth and improve surgical access (Lilja 2009). Dental alignment improves oral hygiene, thereby reducing low-grade inflammation post-operation that may 
cause graft breakdown; correction of central incisor inclination improves surgical access and bone graft placement while also facilitating wound closure (Chang et al. 2016).

Post SABG, loading of the graft occurs as teeth erupt into or are moved orthodontically towards the graft. Sun et al. (2018) showed that initial bone resorption induced by osteoclasts started the bone remodelling process, followed by inflow of osteoblasts. This was proved by the sequential increase of cytokines TRAP, RANKL and RUNX-2, which are established biomarkers of tooth movement (Zainal Ariffin et al. 2011). Comparison between stimulated and non-stimulated grafts shows denser bone at week 8 post-operation in the stimulated graft group. Tooth presence contributes to preservation of the grafted bone and to differentiation of the periodontal support (Da Silva Filho et al. 2000). Approximately $70 \%$ of canines erupt spontaneously within three months of SABG, failing which orthodontic forces may be applied to tract them into position (Da Silva Filho et al. 2000). Current consensus advocates that orthodontic tooth movement (OTM) be commenced six months after SABG, provided that a post-operative cone beam computed tomography result shows successful graft uptake (Shetye 2016). As the growth slows, orthognathic surgery will be indicated in $25-65 \%$ of patients, depending on whether it is a unilateral or bilateral cleft (Daskalogiannakis and Mehta 2009; DeLuke et al. 1997).

\section{TYPES OF BONE GRAFT AND THE ORTHODONTIC IMPLICATIONS}

Important general properties in a bone graft are biocompatibility, ease of sterilization and use, as well as being inexpensive (Damien \& Parsons 1991). Biologically, bone substitute should be able to exhibit elements of osteoconduction, osteoinduction, osteogenesis and osteointegration to form new bone (Laurencin et al. 2006).

The basic requirement of any bone graft is to be 'osteoconductive', that is, the ability of the graft to act as a framework or scaffold upon which osteoblasts and blood vessels from adjacent native bone orientate to create new Haversian systems (Giannoudis et al. 2005; Kumar et al. 2013; Laurencin et al. 2006). 'Osteoinduction' involves the ability of the graft to induce conversion of host mesenchymal cells into osteoprogenitor cells (Damien \& Parsons 1991). The cells within donor bone that contribute to new bone formation by proliferation and differentiation into osteocytes represent the 'osteogeneity' of the graft (Laurencin et al. 2006). The graft finally integrates with native bone through surface bonding (Giannoudis et al. 2005). Only autogenous bone fulfils all the biological characteristic of ideal graft material to date (Moore et al. 2001). Table 1 shows studies in the past 10 years that compared orthodontic outcomes in different types of nonautogenous grafts used in alveolar clefts specifically. The majority of the studies were carried out in animal models, with only one randomized clinical trial conducted by a team from Thailand. While there was no distinct preference

TABLE 1. Studies measuring orthodontic tooth movement in grafted alveolar clefts

\begin{tabular}{|c|c|c|c|c|}
\hline Author(s) & Type of study & $\begin{array}{l}\text { Type of alveolar } \\
\text { defect }\end{array}$ & Type of graft & $\begin{array}{c}\text { Primary outcome } \\
\text { (related to orthodontics) }\end{array}$ \\
\hline $\begin{array}{l}\text { Pradel et al. } \\
(2008)\end{array}$ & Case report & Alveolar cleft & Tissue-engineered bone & $\begin{array}{l}\text { Eruption and migration of } \\
\text { teeth into graft area }\end{array}$ \\
\hline $\begin{array}{l}\text { Thuaksuban et al. } \\
\text { (2010) }\end{array}$ & $\begin{array}{l}\text { Randomized } \\
\text { clinical trial }\end{array}$ & Alveolar cleft & $\begin{array}{l}\text { Iliac bone vs. iliac bone mixed } \\
\text { with xenograft }\end{array}$ & $\begin{array}{c}\text { Spontaneous or } \\
\text { orthodontically-assisted } \\
\text { tooth eruption }\end{array}$ \\
\hline $\begin{array}{l}\text { Zhang et al. } \\
\text { (2011) }\end{array}$ & Animal study & $\begin{array}{l}\text { Simulated cleft } \\
\text { palate }\end{array}$ & $\begin{array}{l}\text { Mesenchymal stem cells on } \beta \text {-TCP } \\
\text { vs. } \beta \text {-TCP alone vs. iliac bone }\end{array}$ & $\begin{array}{l}\text { Amount of OTM } \\
\text { Alveolar bone height }\end{array}$ \\
\hline $\begin{array}{l}\text { Lazarou et al. } \\
\text { (2011) }\end{array}$ & Case series/report & Alveolar cleft & Calcium sulphate (alloplast) & Deciduous tooth eruption \\
\hline $\begin{array}{l}\text { MacIsaac et al. } \\
(2012)\end{array}$ & $\begin{array}{l}\text { Retrospective } \\
\text { cohort }\end{array}$ & Alveolar cleft & $\begin{array}{l}\text { Iliac bone vs. iliac bone mixed } \\
\text { with DBM and allograft }\end{array}$ & $\begin{array}{c}\text { Amount of bone retained } \\
\text { after } 3 \text { months } \\
\text { Tooth eruption as secondary } \\
\text { outcome }\end{array}$ \\
\hline $\begin{array}{l}\text { da Silva Filho et al. } \\
\text { (2013) }\end{array}$ & Case report & $\begin{array}{l}\text { Unilateral } \\
\text { alveolar cleft }\end{array}$ & Allograft & Eruption of canine \\
\hline $\begin{array}{l}\text { Tanimoto et al. } \\
\text { (2015) }\end{array}$ & Animal study & $\begin{array}{l}\text { Simulated cleft } \\
\text { palate }\end{array}$ & $\begin{array}{c}\text { Mesenchymal cells on HA scaffold } \\
\text { vs. empty HA scaffold }\end{array}$ & Amount and rate of OTM \\
\hline $\begin{array}{l}\text { Susarla et al. } \\
(2015)\end{array}$ & $\begin{array}{l}\text { Retrospective } \\
\text { cohort }\end{array}$ & $\begin{array}{l}\text { Uni- and bilateral } \\
\text { alveolar cleft }\end{array}$ & $\begin{array}{l}\text { Iliac crest bone vs. iliac crest } \\
\text { mixed with allograft }\end{array}$ & Velocity of canine eruption \\
\hline $\begin{array}{l}\text { Ru et al. } \\
\text { (2016) }\end{array}$ & Animal study & $\begin{array}{l}\text { Simulated } \\
\text { alveolar cleft }\end{array}$ & $\begin{array}{c}\text { BoneCeramic vs. Bio-Oss }{ }^{\circledR} \text { vs. } \\
\text { negative control }\end{array}$ & $\begin{array}{l}\text { OTM distance and rate, root } \\
\text { resorption and bone changes }\end{array}$ \\
\hline $\begin{array}{l}\text { Hammoudeh et al. } \\
\text { (2017) }\end{array}$ & $\begin{array}{l}\text { Retrospective } \\
\text { cohort }\end{array}$ & Alveolar cleft & $\begin{array}{l}\text { rhBMP-2 mixed with DBM vs. } \\
\text { iliac bone }\end{array}$ & Canine eruption \\
\hline
\end{tabular}


for graft choice, studies that utilized tissue-engineered grafts were limited. The orthodontic outcomes of interest were amount and rate of tooth movement or tooth eruption, root resorption, as well as local bone changes.

\section{AUTOGENOUS BONE}

The success of autogenous bone, especially using cancellous bone from the anterior iliac crest, in alveolar bone grafting is well-established (Boyne \& Sands 1976; Da Silva Filho et al. 2000; Tanimoto et al. 2015). Iliac crest is accessed either through a trapdoor technique or through trephination, depending on the amount of bone required (Thuaksuban et al. 2010). The advantage of using iliac bone is the large amount of harvest and its corticocancellous nature, which provides a combination of osteoinduction and osteoconduction properties with good contractile strength (Coots 2012; Rawashdeh \& Telfah 2008). The main critique of its harvest is the distant operative site pain. However, one study found this argument to be overemphasized and that the pain could be alleviated with a small dose of analgesics (Dawson et al. 1996).

Alternatively, calvaria bone affords advantages such as reduced post-operative morbidity, reduced functional deformity at the donor site, close vicinity to the operating field, good quantity of harvestable bone and inconspicuous scar formation (Eichhorn et al. 2009). Tibial bone could be harvested in a shorter time with a greater amount of good quality bone, allows two surgical teams to work simultaneously, gives less bleeding and produces a smaller scar with no long-term morbidity. However, skeletal growth is restricted in a growing child. Harvesting bone from rib may lead to serious complications such as postoperative chest infection or pneumothorax; and mandible bone may risk injuring the roots of adjacent teeth. These sources are also less popular because of higher morbidity risks due to close proximity to vital organs and slow bony remodelling (Han et al. 2017; Kalaaji et al. 2001; Lilja 2009; Rawashdeh \& Telfah 2008; Tessier et al. 2005; Walker et al. 2009). Use of rib graft especially is discouraged because it leads to difficulty in tooth movement (Coots 2012).

On two-dimensional radiographs, an iliac bone graft is able to maintain up to $11 \mathrm{~mm}$ in bone bridge height in $40 \%$ patients even after 2 years (Tanimoto et al. 2013). Nagashima et al. (2014), however, found that almost 50\% of the graft volume resorbed within 6 months, thus, suggesting earlier orthodontic traction to confer protection against this resorption. The iliac crest can be re-harvested in the future for an interpositional graft after Le Fort I advancement when patients are ready for orthognathic surgery (Posnick \& Gray 2015).

\section{ALLOGRAFTS}

Allografts refer to cadaveric human bone that has been processed through freeze-drying, chemical sterilization and/or irradiation. The last two treatments reduce the osteoconductive property of the graft, therefore freeze- dried bone is the most widely used graft within and outside the dental setting (Malinin et al. 2014). Osteoconductive and osteoinductive properties are conferred by the presence of bone morphogenetic protein (BMP) (da Silva Filho et al. 2013). The exclusive use of allografts is uncommon due to the possibility of disease transmission from donor to host (Laurencin et al. 2006), ineffective osteogenesis of demineralized bone matrix (DBM) in large cleft defects (Madrid et al. 2014) and the high cost (MacIsaac et al. 2012). Hence, allografts are commonly used as an adjunct to autogenous bone grafts in growing children where tooth eruption is incomplete.

Surgical results in terms of bone height and periodontal support of the graft, rate of canine eruption and orthodontic movement were not significantly different whether allografts were used as an adjunct or on their own (da Silva Filho et al. 2013; Susarla et al. 2015). The possibility of canine eruption, however, was lower compared to autogenous bone grafts (MacIsaac et al. 2012).

\section{XENOGRAFTS}

Xenografts are sterilized processed bone from one species that is transplanted into another species (Nazirkar et al. 2014). Researchers found comparable orthodontic results and graft changes compared to iliac bone grafts (Thuaksuban et al. 2010). Total root resorption, measured histologically and morphometrically as a percentage of area (\%), was less when the first permanent molars were moved into composite bovine xenografts compared to untreated extraction sockets in minipigs (Oltramari et al. 2007). This representation of root resorption is different from the commonly reported measurements of root length reduction (in $\mathrm{mm}$ ) or resorption crater volume increment (in $\mathrm{mm}^{3}$ ) (Abdul Wahab et al. 2017). Benlidayi et al. (2012) compared clinical and radiographic outcomes between using bovine xenografts and iliac grafts in SABG. Results were more promising in the former group, with $100 \%$ graft uptake, better patient satisfaction and less resorption. Periodontal parameters were similar in both groups. The results, however, should be interpreted with caution as patient factors were more favourable in the xenograft group (younger age and higher percentage of unerupted canines) and follow-up was significantly longer.

In a large case review by Hammoudeh et al. (2017), 414 patients who received either an autogenous iliac crest bone graft or a recombinant human bone morphogenic protein (rhBMP)-impregnated xenograft were followed over a 12-year period to assess the success of the graft both clinically and functionally. They concluded that there was no difference in functional success (i.e. canine eruption) between both types of graft source. The complications of prolonged intubation and facial swelling requiring steroid therapy, however, should warrant a more detailed explanation. Regardless of the risk-benefit analysis, use of xenografts may still be restricted in certain religions and cultures, such as Hinduism, Jewism and the PETA (People for the Ethical Treatment of Animals) animal rights group 
(Jenkins et al. 2010), as well as for Muslim patients if the graft is porcine.

\section{SYNTHETIC BONE/BONE SUBSTITUTES}

Synthetic bone materials satisfy at most only two of the ideal graft properties: osteointegration and osteoconduction (Moore et al. 2001). In alveolar bone grafting, the synthetic materials most commonly used are beta-tricalcium phosphate ( $\beta$-TCP) and hydroxyapatite (HA). The former has a compressive and tensile strength comparable to cancellous bone and is resorbed within 6-18 months' post insertion. The resorption rate is as high as $60 \%$ but this does not affect functional loading of the graft (De Ruiter et al. 2015).

Hydroxyapatite, on the other hand, resists compression better: ceramic HA is nearly non-resorbable, whereas nonceramic HA resorbs more readily in vivo. 'Ceramic HA' is a highly crystallized structure that has been sintered at a high temperature (Moore et al. 2001). Another source of HA, coralline porous block hydroxyapatite (PBHA), was widely used as an interpositional implant in orthognathic surgery but its use was contraindicated in alveolar clefts as the graft lacked the rigidity for initial stability; also, its inability to obtain watertight closure in cleft cases led to easy contamination of the graft. In addition, PBHA does not resorb, thus tooth movement into the graft will result in significant root resorption (Cottrell \& Larry 1998). A $\mathrm{HA} /$ collagen composite, on the other hand, could be replaced by autogenous bone after 6 months and the total volume did not differ significantly from using an iliac bone graft (Takemaru et al. 2015).

Ceramics of biphasic calcium phosphate (BCP) combine the degradation rate of $\beta$-TCP and the osteoconductivity and biocompatibility of HA in differing proportions (Piattelli et al. 1996). Use of BCP has been well-documented in implant placement (Piattelli et al. 1996) and sinus lifting (Cordaro et al. 2008) procedures. Shamsuddin et al. (2017) showed that the new bone formed was homogenous with surrounding native bone. In orthodontics, Ru et al. (2016) investigated the rate of tooth movement in rats grafted with BoneCeramic, a BCP with $40 \% \beta$-TCP and $60 \% \mathrm{HA}$, and found that it slowed down tooth movement when compared to xenografts. Nonetheless, OTM results in rats should be extrapolated to humans cautiously due to the small tooth size in rats and, consequently, their body adaptation towards orthodontic force (Ibrahim et al. 2017).

\section{TISSUE-ENGINEERED GRAFTS}

To date, human experiments on tissue-engineered bone that employs the use of mesenchymal stem cells to bridge the alveolar cleft remain scarce. Hibi et al. (2006) utilized mesenchymal cells sourced from bone marrow mixed with platelet-rich plasma to induce osteogenesis in the alveolar cleft of a 9-year-old girl. They found bone formation starting after 3 months and the density continued to increase, allowing bone bridging and subsequent eruption of canines and lateral incisors. The presence of mesenchymal stem cells provides the stimulus for angiogenesis within a scaffold, resulting in greater bone formation and remodelling and thus a smoother rate of tooth movement than a control (Tanimoto et al. 2015; Zhang et al. 2011).

Early tooth movement was feasible in the tissueengineered bone group because bone resorption occurred after 4 weeks and new bone formation was seen on week 8 (Sulaiman et al. 2013; Zhang et al. 2011). Nevertheless, more research is required to test this time frame on human subjects. In short, the prospect of tissue engineering to repair an alveolar cleft is very promising but more clinical studies are necessary to determine the resorption or replacement rate of the bone, the effect on orthodontic tooth movement and any possible complications in the long term.

\section{CONCLUSION}

This paper discussed the impact of CLP on orthodontics, with a focus on orthodontic outcomes among different types of bone grafts used in alveolar cleft repair. Tooth movement and tooth eruption were possible in most nonautogenous grafts, except those that do not resorb, such as the coralline PBHA. However, on pooling the findings of the studies selected in this review, we are unable to suggest the best non-autogenous graft to replace autogenous bone. The use of different types of animal models may not provide a meaningful comparison because there is an adaptation difference between animals. Similarly, results from a wrong animal model may not be extrapolated to human trials. There is a niche to establish a suitable animal model for experimenting with the effects of grafts in human cleft alveolus.

While surgical success is obtained in all types of grafts, the functional success and safety of the graft are more important to an orthodontist. Grafts should be stable in order to allow both self-eruption and orthodontic traction of the canines. This should be matched with a resorption rate that is fast enough to prevent unwanted root resorption. New research should measure this as a primary outcome. An autogenous bone graft using the anterior iliac crest remains the graft of choice, but tissue engineering may provide an exciting option in the future.

\section{ACKNOWLEDGEMENTS}

The authors gratefully acknowledge the Universiti Kebangsaan Malaysia through the Fundamental Research Grant Scheme (FRGS/1/2015/SG05/UKM/02/2) from the Ministry of Higher Education Malaysia for providing an opportunity to work on this paper.

\section{REFERENCES}

Abdul Wahab, R.M., Noor Ayuni, A.S. \& Shahrul Hisham, Z.A 2017. An insight into risk factors for root resorption during orthodontic treatment. Journal of Medical Sciences 17(1): 1-9. 
Abdul Wahab, R.M., Nurfathiha, A.K., Sahidan, S., Abdul Aziz, J., Intan Zarina, Z.A., Muhammad Ashraf, S. \& Shahrul Hisham, Z.A. 2014. Enzyme activity profiles and ELISA analysis of biomarkers from human saliva and gingival crevicular fluid during orthodontic tooth movement using self-ligating brackets. Oral Health and Dental Management 13(2): 194-199.

Antonarakis, G.S., Patel, R.N. \& Tompson, B. 2013. Oral health-related quality of life in non-syndromic cleft lip and/ or palate patients: A systematic review. Community Dental Health 30(3): 189-195.

Benlidayi, M.E., Mehmet, U.T., Aslıhan, K.U. \& Haluk, O. 2012. Comparison of bovine-derived hydroxyapatite and autogenous bone for secondary alveolar bone grafting in patients with alveolar clefts. Journal of Oral and Maxillofacial Surgery 70(1): e95-e102.

Bongaarts, C.A.M., Birte, P.A., Ewald, M.B., Paul, H.M.S., Jan, W.M., Michiel, V.J. \& Anne, M.K.J. 2008. Effect of infant orthopedics on facial appearance of toddlers with complete unilateral cleft lip and palate (Dutchcleft). The Cleft PalateCraniofacial Journal 45(4): 407-413.

Boo, N.Y. \& Arshad, A.R. 1990. A study of cleft lip and palate in neonates born in a large Malaysian maternity hospital over a 2-year period. Singapore Medical Journal 31: 59-62.

Boyne, P.J. \& Sands, N.R. 1976. Combined orthodontic-surgical management of residual palato-alveolar cleft defects. American Journal of Orthodontics 70(1): 20-37.

Celebi, A.A., Faruk, I.U., Ahmet, E.S., Murat, C. \& Enes, T. 2015. Effects of cleft lip and palate on the development of permanent upper central incisors: A cone-beam computed tomography study. European Journal of Orthodontics 37(5): 544-549.

Chang, C.S., Christopher, G.W., Hsiao, Y.C., Chiu, Y.T., Betty, C.J.P., Chen, I.J., Liao, Y.F., Eric, J.W.L., Philip, K.T.C., Chen, J.P. \& Samuel, N.M. 2016. Difference in the surgical outcome of unilateral cleft lip and palate patients with and without pre-alveolar bone graft orthodontic treatment. Scientific Reports 6(1): 23597.

Cheng, C.S., Jimeno, S.K.L., Sasidaran, R. \& Sergius, A. 2013. Pilot epidemiological study of cleft lip and/or palate in Kota Kinabalu, Sabah. Asian Journal of Medical Sciences 4(3): 86-91.

Cohen, N. \& Cohen-Lévy, J. 2014. Healing processes following tooth extraction in orthodontic cases. Journal of Dentofacial Anomalies and Orthodontics 17(3): 304.

Cooper, M.E., Jessica, S.R. \& Mary, L.M. 2006. Asian oralfacial cleft birth prevalence. The Cleft Palate-Craniofacial Journal 43(5): 580-589.

Coots, B.K. 2012. Alveolar bone grafting: Past, present, and new horizons. Semin. Plast. Surg. 26(4): 178-184.

Cordaro, L., Dieter, D.B., Piermario, P., Walter, R., Serino, G. \& Matteo, C. 2008. Maxillary sinus grafting with Bio-Oss ${ }^{\circledR}$ or Straumann ${ }^{\circledR}$ bone ceramic: Histomorphometric results from a randomized controlled multi-center clinical trial. Clinical Oral Implants Research 19(8): 796-803.

Cottrell, D.A. \& Larry, M.W. 1998. Long-term evaluation of the use of coralline hydroxyapatite in orthognathic surgery. Journal of Oral and Maxillofacial Surgery 56(8): 935-941.

Damien, C.J. \& Parsons, J.R. 1991. Bone graft and bone graft substitutes: A review of current technology and applications. Journal of Applied Biomaterials 2(3): 187-208.

Daskalogiannakis, J. \& Mehta, M. 2009. The need for orthognathic surgery in patients with repaired complete unilateral and complete bilateral cleft lip and palate. The Cleft Palate-Craniofacial Journal 46(5): 498-502.
Dawson, K.H., Egbert, M.A. \& Myall, R.W.T. 1996. Pain following iliac crest bone grafting of alveolar clefts. Journal of Cranio-Maxillofacial Surgery 24(3): 151-154.

da Silva Filho, O.G., Ozawa, T.O., Bachega, C. \& Bachega, M.A. 2013. Reconstruction of alveolar cleft with allogenous bone graft: Clinical considerations. Dental Press Journal of Orthodontics 18(6): 138-147.

da Silva Filho, O.G., Teles, S.G., Ozawa, T.O. \& Filho, L.C. 2000. Secondary bone graft and eruption of the permanent canine in patients with alveolar clefts: Literature review and case report. Angle Orthodontist 70(2): 174-178.

da Silva, W.S., de Almeida, A.L.P.F., Pucciarelli, M.G.R., Neppelenbroek, K.H., da Silva de Menezes, J.D., Yaedú, R.Y.F., Oliveira, T.M., Cintra, F.M.R.N. \& Soares, S. 2018. Relapse after Le Fort I surgery in oral cleft patients: A 2 year follow up using digitized and 3D models. Odontology 106(4): 445-453.

DeLuke, D.M., Marchand, A., Robles, E.C. \& Fox, P. 1997. Facial growth and the need for orthognathic surgery after cleft palate repair: Literature review and report of 28 cases. Journal of Oral and Maxillofacial Surgery 55(7): 694-697.

Dewinter, G., Quirynen, M., Heidbüchel, K., Verdonck, A., Willems, G. \& Carels, C. 2003. Dental abnormalities, bone graft quality, and periodontal conditions in patients with unilateral cleft lip and palate at different phases of orthodontic treatment. The Cleft Palate-Craniofacial Journal 40(4): 343-350.

Eichhorn, W., Marco, B., Philipp, P., Felix, A.S., Blake, G.G., Rainer, S. \& Max, H. 2009. Primary osteoplasty using calvarian bone in patients with cleft lip, alveolus and palate. Journal of Cranio-Maxillofacial Surgery 37(8): 429-433.

Giannoudis, P.V., Haralambos, D. \& Eleftherios, T. 2005. Bone substitutes: An update. Injury 36(3): S20-S27.

Guo, J., Chunjie, L., Qifeng, Z., Gang, W., Scott, D., Jianwei, C., Haikun, H., Shujuan, Z. \& Qingsong, Y. 2011. Secondary bone grafting for alveolar cleft in children with cleft lip or cleft lip and palate. Cochrane Database of Systematic Reviews(Online) 15(6): CD008050.

Hammoudeh, J.A., Artur, F., Daniel, J., Gould, F.L., Thomas, I., Leo, U., Jo, A.T.N., Stephen, Y.W.M. \& Mark, M.U. 2017. A comparative analysis of recombinant human bone morphogenetic protein-2 with a demineralized bone matrix versus iliac crest bone graft for secondary alveolar bone grafts in patients with cleft lip and palate: Review of 501 cases. Plastic and Reconstructive Surgery 140(2): $318 \mathrm{e}-325 \mathrm{e}$.

Han, K., Woonhyeok, J., Hyeonjung, Y., Jaehoon, C., Junhyung, K., Daegu, S., Sangho, O. \& Changhyun, K. 2017. Longterm results of secondary alveolar bone grafting using a technique to harvest pure calvarial cancellous bone: Evaluation based on plain radiography and computed tomography. Journal of Plastic, Reconstructive \& Aesthetic Surgery 70(3): 352-359.

Hibi, H., Yamada, Y., Ueda, M. \& Endo, Y. 2006. Alveolar cleft osteoplasty using tissue-engineered osteogenic material. International Journal of Oral and Maxillofacial Surgery 35(6): 551-555.

Ibrahim, A.Y., Gudhimella, S., Pandruvada, S.N. \& Huja, S.S. 2017. Resolving differences between animal models for expedited orthodontic tooth movement. Orthodontics \& Craniofacial Research 20(6): 72-76.

Janssen, N.G., Willem, L.J.W., Ronald, K., Antoine, J.W.P.R. \& Gert, J.M. 2014. Tissue engineering strategies for alveolar cleft reconstruction: A systematic review of the literature. Clinical Oral Investigations 18(1): 219-226. 
Jenkins, E.D., Michael, Y., Lora, M., Margaret, M.F. \& Brent, D.M. 2010. Informed consent: Cultural and religious issues associated with the use of allogeneic and xenogeneic mesh products. ACS 210: 402-410.

Kalaaji, A.J.L., Elander, A. \& Friede, H. 2001. Tibia as donor site for alveolar bone grafting in patients with cleft lip and palate: Long-term experience. Scandinavian Journal of Plastic and Reconstructive Surgery and Hand Surgery 35(1): 35-42.

Kreiborg, S., Herman, N.V. \& Darvann, T.A. 2013. Characteristics of facial morphology and growth in infants with clefts. In Cleft Lip and Palate: Diagnosis and Management, 3rd ed., edited by Berkowitz, S. Berlin, Heidelberg: Springer. pp. 245-257.

Kumar, P., Ghousia, F. \& Belliappa, V. 2013. Bone grafts in dentistry. Journal of Pharmacy and Bioallied Sciences 5(1): S125-S127.

Laurencin, C., Yusuf, K. \& Saadiq, F.E.A. 2006. Bone graft substitutes. Expert Review of Medical Devices 3(1): 4957.

Lazarou, S.A., Contodimos, G.B. \& Gkegkes, I.D. 2011. Correction of alveolar cleft with calcium-based bone substitutes. Journal of Craniofacial Surgery 22(3): 854857.

Lilja, J. 2009. Alveolar bone grafting. Indian Journal of Plastic Surgery 42: S110-S115.

López-Giménez, A., Javier, S.R., Francisco, J.S. \& Vanessa, P.G. 2018. Tooth agenesis code (TAC) in complete unilateral and bilateral cleft lip and palate patients. Odontology 106(3): 257-265.

MacIsaac, Z.M., Alex, R.S., Alexander, J.D., Matthew, F., Joseph, E.L. \& Anand, R.K. 2012. Alveolar reconstruction in cleft patients: Decreased morbidity and improved outcomes with supplemental demineralized bone matrix and cancellous allograft. Plastic and Reconstructive Surgery 130(3): 625-632.

Malinin, T.I., Temple, H.T. \& Garg, A.K. 2014. Bone allografts in dentistry: A review. Dentistry 4: 2.

Meikle, M.C. 2005. The tissue, cellular, and molecular regulation of orthodontic tooth movement: 100 years after Carl Sandstedt. The European Journal of Orthodontics 28(3): 221-240.

Menezes, L.M.D., Rizzatto, S.M.D., Allgayer, S., Heitz, C. \& Burnett, L.H. 2012. The importance of interdisciplinary approach for managing cleft lip and palate: A case report. Journal of the World Federation of Orthodontists 1(3): 103113.

Miller, L.L., Kauffmann, D., St. John, D., Wang, D., Grant III., J.H. \& Waite, P.D. 2010. Retrospective review of 99 patients with secondary alveolar cleft repair. Journal of Oral and Maxillofacial Surgery 68(6): 1283-1289.

Moore, W.R., Stephen, E.G. \& Gregory, I.B. 2001. Synthetic bone graft substitutes. ANZ Journal of Surgery 71(6): 354361.

Munz, S.M., Edwards, S.P. \& Inglehart, M.R. 2011. Oral healthrelated quality of life, and satisfaction with treatment and treatment outcomes of adolescents/young adults with cleft lip/palate: An exploration. International Journal of Oral \& Maxillofacial Surgery 40: 790-796.

Nagashima, H., Yoshiaki, S., Hisao, O., Junpei, M., Masaki, Y. \& Kazuo, K. 2014. Evaluation of bone volume after secondary bone grafting in unilateral alveolar cleft using computer-aided engineering. The Cleft Palate-Craniofacial Journal 51(6): 665-668.
Nazirkar, G., Shailendra, S., Vinaykumar, D. \& Akhilesh, N. 2014. Effortless effort in bone regeneration: A review. Journal of International Oral Health 6(3): 120-124.

Oltramari, P.V.P., Ricardo, de Lima, N., José, F.C.H., Rumio, T., Tania, M.C., Daniele, S.C., Guilherme, J. \& José, M.G. 2007. Orthodontic movement in bone defects filled with xenogenic graft: An experimental study in minipigs. American Journal of Orthodontics and Dentofacial Orthopedics 131(3): 10-17.

Piattelli, A., Scarano, A. \& Mangano, C. 1996. Clinical and histologic aspects of biphasic calcium phosphate ceramic (BCP) used in connection with implant placement. Biomaterials 17(18): 1767-1770.

Politis, C., Joseph, S., Reinhilde, J. \& Jimoh, O.A. 2016. Wound healing problems in the mouth. Frontiers in Physiology 7: 507.

Posnick, J.C. \& Gray, J.A. 2015. Is it safe to re-harvest the anterior iliac crest to manage Le Fort I interpositional defects in young adults with a repaired cleft? Journal of Oral and Maxillofacial Surgery 73(12): S32-S39.

Pradel, W., Tausche, E., Gollogly, J. \& Lauer, G. 2008. Spontaneous tooth eruption after alveolar cleft osteoplasty using tissue-engineered bone: A case report. Oral Surgery, Oral Medicine, Oral Pathology, Oral Radiology and Endodontology 105(4): 440-444.

Rawashdeh, M.A. \& Telfah, H. 2008. Secondary alveolar bone grafting: The dilemma of donor site selection and morbidity. British Journal of Oral and Maxillofacial Surgery 46(8): 665-670.

Reichert, C., Werner, G., Ralf, S., Mathias, W. \& Andreas, J. 2010. The impact of nonautogenous bone graft on orthodontic treatment. Quintessence International (Berlin, Germany: 1985) 41(8): 665-672.

Reiser, E., Anna, A.S., Maria, M. \& Mats, H. 2011. Initial size of cleft does not correlate with size and function of nasal airway in adults with unilateral cleft lip and palate. Journal of Plastic Surgery and Hand Surgery 45(3): 129135.

Reiser, E., Valdemar, S., Bengt, G. \& Anna, A.S. 2010. Association between cleft size and crossbite in children with cleft palate and unilateral cleft lip and palate. The Cleft Palate-Craniofacial Journal 47(2): 175-181.

Ru, N., Sean, S.Y.L., Yuxing, B., Song, L., Yunfeng, L. \& Xiaoxia, W. 2016. Bone ceramic graft regenerates alveolar defects but slows orthodontic tooth movement with less root resorption. American Journal of Orthodontics and Dentofacial Orthopedics 149(4): 523-532.

Ruiter, A.D., Nard, J., Robert, V.E., Michael, F., Gert, M., Ron, K. \& Toine, R. 2015. Micro-structured beta-tricalcium phosphate for repair of the alveolar cleft in cleft lip and palate patients: A pilot study. The Cleft Palate-Craniofacial Journal 52(3): 336-340.

Shah, S.Y.A., Abdul Rahman, Z.A., Mirani, S.A., Shaikh, M.I., Khattak, M.N. \& Sahito, M.A. 2015. Demographic data on the characterization of oral clefts in Malaysia. Pakistan Oral \& Dental Journal 35(1): 108-110.

Shamsuddin, S.A., Roszalina, R., Masfueh, R., Badiah, B., Shamsul, S., Min, H.N., Cheong, K.L., Low, C.K., Jabar, M.N.A., Nordin, R., Yahaya, N., Shukur, S.S.A., Siar, C.H. $\&$ Ruszymah, H.I. 2017. Guided bone regeneration using autologous plasma, bone marrow cells and $\beta$-TCP/HA granules for experimental alveolar ridge reconstruction in Macaca fascicularis. Journal of Biomaterials and Tissue Engineering 7(2): 111-118. 
Shetye, P.R. 2016. Update on treatment of patients with cleft-timing of orthodontics and surgery. Seminars in Orthodontics 22(1): 45-51.

Siti Adibah, O. \& Noor Airin, A.K. 2016. Three-dimensional facial analysis of Chinese children with repaired unilateral cleft lip and palate. Scientific Reports 6(1): 313-335.

Sulaiman, S., Tan, K.K., Chen, H.C., Aminuddin, S. \& Ruszymah, H.I. 2013. Tricalcium phosphate/hydroxyapatite (TCP-HA) bone scaffold as potential candidate for the formation of tissue engineered bone. The Indian Journal of Medical Research 137(6): 1093-1101.

Sun, J., Zhang, X.Y., Li, R.M., Chen, Z.X., Huang, Y.L. \& Chen, Z.Q. 2018. Biological effects of orthodontic tooth movement into the grafted alveolar cleft. Journal of Oral and Maxillofacial Surgery 76(3): 605-615.

Susarla, S.M., Andrews, R., Hilal, N., Swanson, E.W., Susarla, H.K., Martin, B.S. \& Kumar, A.R. 2015. Is canine eruption velocity affected by the presence of allograft within a repaired alveolar cleft? Journal of Oral and Maxillofacial Surgery 73(10): 1888-1893.

Takemaru, M., Sakamoto, Y., Sakamoto, T. \& Kishi, K. 2015. Assessment of bioabsorbable hydroxyapatite for secondary bone grafting in unilateral alveolar cleft. Journal of Plastic, Reconstructive and Aesthetic Surgery 69(4): 493-496.

Tanimoto, K., Sumi, K., Yoshioka, M., Oki, N., Tanne, Y., Awada, T., Kato, Y., Sugiyama, M. \& Tanne, K. 2015. Experimental tooth movement into new bone area regenerated by use of bone marrow-derived mesenchymal stem cells. The Cleft Palate-Craniofacial Journal 52(4): 386-394.

Tanimoto, K., Tanne, Y., Sumi, K., Hirose, N., Kawai, N., Tanaka, E. \& Tanne, K. 2013. Longitudinal changes in the height and location of bone bridge from autogenous iliac bone graft in patients with cleft lip and palate. Open Journal of Stomatology 03(01): 58-62.

Tessier, P., Kawamoto, H., Posnick, J., Raulo, Y., Tulasne, J.F. \& Wolfe, S.A. 2005. Complications of harvesting autogenous bone grafts: A group experience of 20,000 cases. Plastic and Reconstructive Surgery 116(5): 72-73.

Thuaksuban, N., Nuntanaranont, T. \& Pripatnanont, P. 2010. A comparison of autogenous bone graft combined with deproteinized bovine bone and autogenous bone graft alone for treatment of alveolar cleft. International Journal of Oral and Maxillofacial Surgery 39(12): 1175-1180.

Uzel, A. \& Alparslan, Z.N. 2011. Long-term effects of presurgical infant orthopedics in patients with cleft lip and palate: A systematic review. The Cleft Palate-Craniofacial Journal 48(5): 587-595.

Walker, T.W.M., Prince, C.M., Luke, C., Luke, W., Simon, M.D. \& Peter, W.B. 2009. Retrospective review of donor site complications after harvest of cancellous bone from the anteriomedial tibia. British Journal of Oral and Maxillofacial Surgery 47(1): 20-22.
Weissler, E.H., Kaitlyn, M.P., Mairaj, K.A. \& Peter, J.T. 2016. Alveolar bone grafting and cleft lip and palate: A review. Plastic and Reconstructive Surgery 138(6): 1287-1295.

Zainal Ariffin, S.H., Zulham, Y., Intan Zarina, Z.A., Rohaya, M.A.W. \& Zaidah, Z.A. 2011. Cellular and molecular changes in orthodontic tooth movement. The Scientific World Journal 11(10): 1788-1803.

Zhang, D., Chu, F., Yang, Y., Xia, L., Zeng, D., Uludağ, H., Zhang, X., Qian, Y. \& Jiang, X. 2011. Orthodontic tooth movement in alveolar cleft repaired with a tissue engineering bone: An experimental study in dogs. Tissue EngineeringPart A 17(9-10): 1313-1325.

Zhou, W., Weiran, L., Jiuxiang, L., Denggao, L., Xiaoyan, X. \& Zuyan, Z. 2013. Tooth lengths of the permanent upper incisors in patients with cleft lip and palate determined with cone beam computed tomography. The Cleft PalateCraniofacial Journal 50(1): 88-95.

Zreaqat, M., Hassan, R. \& Halim, A.S. 2012. facial dimensions of Malay children with repaired unilateral cleft lip and palate: A three dimensional analysis. International Journal of Oral \& Maxillofacial Surgery 41: 783-788.

Rohaya Megat Abdul Wahab*, Wan Ching Ng \& Nur Atmaliya Luchman

Discipline of Orthodontics

Department of Family Oral Health

Faculty of Dentistry

Universiti Kebangsaan Malaysia

Jalan Raja Muda Aziz

50300 Kuala Lumpur, Federal Territory

Malaysia

Farinawati Yazid

Discipline of Paediatric Dentistry

Department of Family Oral Health

Faculty of Dentistry

Universiti Kebangsaan Malaysia

Jalan Raja Muda Aziz

50300 Kuala Lumpur, Federal Territory

Malaysia

Shahrul Hisham Zainal Ariffin

Department of Biotechnology and Functional Food

Faculty of Science and Technology

Universiti Kebangsaan Malaysia

43600 Bangi, Selangor Darul Ehsan

Malaysia

*Corresponding author; email: rohaya_megat@ukm.edu.my

Received: 12 February 2019

Accepted: 6 November 2019 